\title{
SPECIFICS OF EMPLOYEE COMPETENCIES IN RELIGIOUS TOURISM
}

\author{
Nikica Radović ${ }^{1}$ \\ Marina Savković, \\ Nataša Stanišić, \\ Dragan Vukić
}

${ }^{1}$ Singidunum University, Belgrade, Serbia

2PA Dobročinstvo
Correspondence:

Nikica Radović

e-mail:

nradovic@singidunum.ac.rs

\section{Abstract:}

Employee competencies are the key to success in all economic activities, particularly in the service sector. Numerous studies of elements and models of employee competency in different sectors, including the tourism sector, support this conclusion. However, little attention has been directed to the specific competencies of employees working in specialised forms of tourism, i.e. the so-called thematic tourism, including religious tourism. In this paper, we attempt to highlight these specificities and propose an employee competency model in the field of religious tourism. The developed framework may serve as a starting point for further research. Likewise, the proposed solution may become an integral element of policies in the field of promotion and development of religious tourism in Serbia and abroad.

\section{Keywords:}

employee competencies, religious tourism.

\section{INTRODUCTION}

The development and trends in the international tourism market are predominantly based on mass tourism forms, i.e. the most common types of tourism, the tourism of "sun and sea". However, the circumstances and interests of tourists in the tourism market have been gradually changing, becoming increasingly more focused on frequent and shorter tours based on alternative concepts. These tours are based on different requirements and interests of tourists, as well as specific activities and topics, thus constituting a new type of tourism, the so-called thematic tourism. According to Jovanović (2015), these changes are caused by different ways of life and work, and as a result, the concept of vacation and total tourism has been changing and adapting to the specific interests of tourists. The special interest tourism has been defined by Rabotić (2012) as a form of tourism that includes users of tourism services whose travel choices are driven by specific motivations and whose level of satisfaction determines the overall travelling experience.

The thematic tourism trends include: health (medical) tourism, urban tourism, business tourism, spa tourism, rural tourism, eco-tourism, nautical tourism, sport tourism, educational tourism, cultural tourism and religious tourism. The main objective of this paper is to analyse the bases for the development of religious tourism through the development 
of human resources, as well as the competencies of employees in the agencies and organizations that organize pilgrimage tours. In this paper, based on an analysis of the characteristics and forms of religious tourism, the general framework of competencies of employees working in the field of tourism will be analysed while highlighting the knowledge, skills and attitudes that are of particular importance to this specific type of tourism. Finally, a case study of an organization engaged in pilgrimage tourism will be presented, providing hands-on insight into actual competencies of employees, allowing us to make conclusions about the specifics of the quality of human resources in the given context.

\section{RELIGIOUS TOURISM}

Religious tourism is one of the oldest forms of travel, whose objective is to visit a sacred site for the purpose of pilgrimage, religious need, feeling or obligation, which are reflected in the exercise of prayer, pilgrimage and osculation of relics of saints with the aim of healing illnesses, as well as finding spiritual peace.

The World Association of Religious Travel (WRTA) defines religious tourism as "travel to religious destinations, travel to religious gatherings, travel with missionary and/or humanitarian intentions and travel with the intention of fellowship, companionship and friendship." (Nikolić, 2010)

Šećibović (1995) points to a division of religious tourism made by the German geographer Gisbert who, based on the length of stay, i.e. the duration of visit to a holy site, distinguishes two types of religious tourism:

a) Short-term religious tourism related to travels limited to small distances with the goal of visiting a local or regional religious centre to take part in a religious celebration, a conference or a church synod. This group of tours includes visits to monasteries. The visits to monasteries may be realized from several aspects: from the point of a believer who comes to worship and osculate the relics of saints committed to those monasteries and churches as part of a complex, as well as from the point of a tourist who visits monasteries as cultural and historical tourist resources, bearing in mind the architectural diversity and treasures present in our monasteries. Additionally, the monasteries of the Serbian Orthodox Church were, for a long period of time in Serbian history, the centres for preserving Serbian culture and tradition, as well as literacy. Even today, monasteries organize religious schools and educational workshops with the aim of preserving the history, culture and religion of the Serbian people (monastery Soko grad near LjubovijaMOBA, icon-painting and wood-carving school in the Lelić monastery, icon-painting and weaving workshop in the Gradac monastery, etc.).

b) Long-term religious tourism, which encompasses visits to religious centres lasting for several days. This type of tourism usually includes pilgrimages and is present in all religions of the world (Jerusalem, Mecca, Rome, Benarez).

In view of the fact that religious tourism represents a specific form of tourist movements, Stamenković (2006) has identified the key factors that implementers of these types of tours need to take into account, such as: product, price, promotion, distribution, emergent processes and forms, and in particular individuals, i.e. employees. In this sense, it is the skills of employees, developed through a process of formal education, provided in the tourism sector by publicly recognized qualification degrees, as well as through work experience, which are crucial (NOKS, 2013; ILO, 2006).

\section{COMPETENCIES OF EMPLOYEES IN TOURISM INDUSTRY}

One of the features that characterize the tourism sector is human resources, i.e. employees, as an important link in the process of service delivery. Their importance is reflected in the fact that employees are in touch and communicating with potential users of services, thus establishing a specific communication and leaving a certain impression and attitude not just of the employee himself (or herself), but also of the tour operator/agency. The dynamism that characterizes the tourism sector leads to the need for worker flexibility, both in terms of concluding atypical work agreements (Juul, 2015; RPA, 2012) and in terms of employee knowledge and skills. The requirements are aimed at performing different tasks and functions, which necessitate multifunctional and multidisciplinary worker knowledge and skills that can fit into a shifting and challenging work environment (Stefanović, Blagojević, 2009).

The employees, their development, satisfaction and motivation are key to market success. The idea is for tour operators/agencies to begin applying competency models to determine the personal characteristics, skills and knowledge that are necessary for the implementation of appropriate business activities in tourism. Competency could be defined as an overall prerequisite for work performance (Bahtijarević, Sunroof, 1999). 
Fundamentally, competencies are abilities, i.e. an employee's capabilities to perform specific business tasks or activities. In addition to knowledge and skills in the classic sense, competencies include attitudes and characteristics of employees needed to perform a specific job. Thus defined, competencies require proving the existence and level of knowledge, skills and attitudes or traits that employees in a specific sector possess. The aforementioned proof or outcome is usually assessed through content, intensity and level of formal and informal educational programmes, as well as through performance assessment at a specific job (ILO, 2006).

According to Bahtijarević-Šiber (1999), competencies are generally divided into four categories: intellectual, interpersonal, related to adaptability and results-oriented. Following a further analysis, the individual competencies related to specific business activities have been defined and presented in Table 1. A more detailed analysis of competencies would allow us to distinguish: general competencies, which all employees in a particular sector or organisation must possess, and specific competencies, which are related to a particular job. Specific employee competencies are acquired through hands-on experience (NOKS, 2013), as well as formal education process. Higher education plays a significant role here, as it pays special attention to the development of managerial competencies of tourism workers (Breen, Walo \& Dimmock, 2004; Cizel, Anafarta \& Sarvan, 2007).
Table1. Employee competencies

\begin{tabular}{|c|c|}
\hline $\begin{array}{c}\text { GENERAL } \\
\text { COMPETENCIES }\end{array}$ & $\begin{array}{c}\text { SPECIFIC } \\
\text { COMPETENCIES }\end{array}$ \\
\hline Intellectual & $\begin{array}{l}\text { Strategic perspective / } \\
\text { Analysis and evaluation } \\
\text { Planning and organizing }\end{array}$ \\
\hline Interpersonal & $\begin{array}{c}\text { Personnel management / } \\
\text { Credibility } \\
\text { Assertiveness and } \\
\text { determination / } \\
\text { Interpersonal sensitivity / } \\
\text { Oral communication }\end{array}$ \\
\hline Adaptability & $\begin{array}{c}\text { Adaptability and mobility / } \\
\text { Flexibility }\end{array}$ \\
\hline Results-oriented & $\begin{array}{c}\text { Energy and initiative / } \\
\text { Achievement motivation } \\
\text { Business sense }\end{array}$ \\
\hline
\end{tabular}

Source: Bahtijarević-Šiber, F, 1999.

The research conducted by Cerer and Mesenlehner (2009) indicates that employers in the tourism sector insist on a multifunctional set of competencies where technical competencies are not favoured in relation to interpersonal competencies and personality traits. In that respect, the narrowly professional competencies are not given priority over the general knowledge acquired by students of social sciences or tourism workers in practice, yet they remain important for working with people in a changing business environment.

Table 2. Knowledge required in tourism

\begin{tabular}{llll}
\hline $\begin{array}{l}\text { Knowledge and } \\
\text { competencies }\end{array}$ & Managers & Expert associate & All employees \\
\hline - Planning and organizing & - Computer skills & - Professional competencies & - Professional competencies \\
- Customer-focused & - Business planning & - Problem-solving & - Technical skills \\
- Communication & - Management skills & - Basic computer skills & - On-the-job training \\
- Knowledge of foreign & - Change management & - Knowledge innovation & - Personal development \\
languages & - Performance management & - Project and work process & - Occupational safety \\
- Cultural understanding & - Decision-making & management & - Customer- and \\
- Teamwork & - Human resource & - Communication & result-focused \\
- Flexibility & management & - Specialised competencies & \\
- Problem-solving & - Destination management & - Presentation skills & \\
- Training skills & - Project management & -Creativity and innovation & \\
- Personnel management & - Education for teaching & & \\
& others & &
\end{tabular}

Source: Stefanović, V., Blagojević, S., (2009), Menadžment ljudskih resursa u turizmu, PMF, Novi Sad, p. 505 


\section{COMPETENCIES OF EMPLOYEES WORKING IN RELIGIOUS TOURISM}

Religious tourism is characterized by a number of specificities in the realization of tourism services. Thus, we have assumed that a specific employee profile would be needed for work in organizations that organize and carry out tours related to this segment of tourist interests. Specifically, the nature of tours that are carried out within the segment of religious tourism is based on specific topics, locations, and interests of tourists of different psycho-social structures. For that reason, Stamenković (2006) asserts that in this particular case the knowledge of general psychology and business psychology is desirable, obtained by cultivating traits such as communication skills, tact, self-confidence, resourcefulness, patience, confidentiality, positivity and cheerfulness, sticking to one's principles, being a good listener, rather than being intrusive and boring, but with a "measure of good communication."

Assuming that employees who organize and carry out tours in the field of religious tourism possess, to a certain extent, different competencies in relation to other tourism workers, we have analysed the following set of competencies, adapted from the model presented in Table 2.

- Education and qualifications

- Customer-focused

- Communication skills

- Knowledge of foreign languages

- Cultural understanding

- Tolerance

- Computer skills

- General and business culture

- Flexibility

- Teamwork

- Problem-solving

- Personnel management

- Occupational safety

\section{CASE STUDY - PILGRIMAGE AGENCY DOBROČINSTVO ("CHARITY")}

The Pilgrimage Agency Dobročinstvo (in Serbian: "Charity"), a pioneer in the field of religious tourism in Serbia, was established in 1990 by the Serbian Orthodox Church with the intention of introducing users of tourism services to the monuments of Serbian spirituality, culture and traditions by means of well-designed travel programmes. Its portfolio contains more than thirty domestic and twenty foreign pilgrimage travel programmes encompassing visits to some two hundred churches and monasteries of importance to the culture and spirituality of the Orthodox countries. Tours are carried out throughout the year, and thus far more than 80,000 passengers have travelled with this pilgrimage agency both domestically and worldwide.

For the purposes of travel organization, a team of employees was assembled in PA Dobročinstvo whose high level of competencies help organize and carry out travel programmes showcasing the treasures of spirituality and art of the Orthodox people and the countries with rich Christian culture, such as: Following the Bible - Israel and Jordan, visits to the Holy Land, Mount Athos, Russian sacred sites, monasteries in Romania, Bulgaria, with numerous visits to monasteries/sacred sites in Serbia.

Since its inception, PA Dobročinstvo has been headed by Dragan Vukić, a graduate theologian by education. As director of the agency, he has recruited associates from the field of tourism, successfully combining the knowledge of theology and tourism in order to respond to the specific requirements of the religious tourism user base. Table 3 shows the structure of personnel employed by PA Dobročinstvo.

Table 3. Structure of personnel employed by pa dobročinstvo

\begin{tabular}{cc}
\hline Graduate Theologian & Director \\
\hline Graduate Tourismologist & Sales Specialist \\
\hline $\begin{array}{c}\text { Bachelor of } \\
\text { Applied Economics }\end{array}$ & Sales Specialist \\
\hline Graduate Tourismologist & Sales Officer \\
\hline $\begin{array}{c}\text { Bachelor of } \\
\text { Applied Economics }\end{array}$ & Sales Officer \\
\hline $\begin{array}{c}\text { Bachelor of } \\
\text { Applied Economics }\end{array}$ & Sales Officer \\
\hline
\end{tabular}

Source: Researchers' own data

The PA Dobročinstvo employs six people, one director of the agency, two sales specialists and three sales officers. Based on an analysis of employee competencies, using the data from Tables 2 and 3 , though indicating a very high level of employee competency, the organization management does not specifically highlight the importance of any of the analysed competences, but rather emphasises the importance of all employee competencies in the classic tourism sector. 
On the other hand, the duration of stay at the target destination- monasteries/sacred sites - is extremely important to users of religious tourism services. Bearing in mind the basis of this form of thematic tourism - faith, hope, spirituality, peace and tranquillity, it should be emphasised here that visits to monasteries/sacred sites are carried out with the expert help of Dobročinstvo tour guides, with the possibility of cooperation with individual monks or priests as hosts, if that is their obedience task, taking into account the specific way of life in monasteries and the monastic tipik. ${ }^{1}$

\section{CONCLUDING REMARKS}

Our analysis has shown that the differences between the competencies of employees working in the general sector of tourism and employees working in religious tourism are relatively minor. Some differences can be seen at the management level of an organization, which governs its mission and strategy and develops business content. In this regard, we emphasise once again the need for multidisciplinary and multifunctional competencies of employees working in the tourism sector. In addition to formal education, which provides a basic level of professional and managerial competency, emphasis is to be placed on the knowledge and skills acquired through the actual performance of a particular job. It is through the organization and delivery of religious or pilgrimage travel that the specificity of knowledge, skills and attitudes is developed that characterizes employees working in the field of religious tourism.

\section{REFERENCES}

Bahtijarević Šiber, F. (1999). Menadžment ljudskih poten cijala. Zagreb: Golden marketing.

Breen, H., Walo, M., \& Dimmock, K. (2004). Assessment of tourism and hospitality management competencies: a student perspective in K. A. Smithe \& C. Schott (eds). Proceedings of Tourism research: advances and applications, New Zealand Tourism and Hospitality Research Conference, 8-10. Tourism Management Group, Victoria Management School, Victoria University of Wellington: Wellington, NZ.

Cizel, B., Anafarta, N., Sarvan, F. (2007). An analysis of managerial competency needs in tourism sector: the case of Turkey. Tourism Review. 62(2),14-22.

ILO (2006). Regional Model Competency Standard: Tourism Industry, Regional Skills and Employability Programme in Asia and the Pacific. Bangkok: International Labour Office.

Jovanović, V. (2015).Tematski turizam. Beograd: Univerzitet Singidunum

Juul, M. (2015). Turism and The European Union - Recent trends and policy developments, DirectorateGeneral for Parliamentary Research Services. Brussels: European Parliament

Ministarstvo prosvete, nauke i tehnološkog razvoja, Zavod za unapređivanje obrazovanja i vaspitanja (2013). Nacionalni okvir kvalifikacija. Beograd.

Nikolić, V. (2010). Verski turizam i Srpska pravoslavna crkva. Doktorska disertacija. Beograd: Univerzitet Singidunum.

Rabotić, B. (2012). Selektivni oblici turizma. Beograd: Visoka turistička škola strukovnih studija.

RPA (2012). Study on the impact of EU policies and the measures undertaken in their framework on tourism. Prepared for DG Enterprise and Industry, Final report.1. Retrieved 20 May 2017 from http:// www.ris3balears.org/wp-content/uploads/2013/06/ impact-of-EU-measures-on-tourism.pdf.

Stamenković, I. (2006). Religiozni turizam i pravoslavlje. Novi Sad: PMF.

Stefanović, V., Blagojević, S., (2009). Menadžment ljudskih resursa u turizmu. Novi Sad: Prirodno matematički fakultet.

Šećibović, R. (1995). Uvod u opštu geografiju religije. Novi Sad: Prometej. Beograd:Tersit.

Zehrer, A., Moessenlechner C. (2009). Key Competencies of Tourism Graduates: The Employers' Point of View. Journal of Teaching in Travel and Tourism. 9(3-4), 266-287.

1 Tipik- rules governing the life of monks in a monastery, as well as the rules of worship 